\title{
端部に垂直壁が設置された水平上向き加熱平板まわりの 自然対流の流動と伝熱*
}

\author{
木 村 文 義*1, 石 原 英 ${ }^{* 2}$, 北 村 健 三*3
}

Flow and Heat Transfer of Natural Convection around

Upward-Facing Horizontal Plate with a Vertical Plate at the Edge

\author{
Fumiyoshi KIMURA*4, Suguru ISHIHARA and Kenzo KITAMURA \\ ${ }^{* 4}$ Department of Mechanical and System Engineering, Himeji Institute of Technology, \\ 2167 Shosha, Himeji-shi, Hyogo, 671-2201 Japan
}

\begin{abstract}
Natural convective flows around upward-facing horizontal heated plate with a vertical plate at the edge were investigated experimentally. The widths of horizontal heated plates, $W$, and the heights of vertical plates, $H$, were varied systematically as $W=100 \sim 350 \mathrm{~mm}$ and $H=0 \sim 150 \mathrm{~mm}$. The flow fields and the surface temperatures of the horizontal plates were visualized with dye and liquid crystal thermometry. The result shows that the vertical plate blocks incoming flow from the edge, and that the flow entering from the open edge covers the whole horizontal surface when the height of the vertical plate exceeds $H / W=0.14$ for the adiabatic vertical plate and $H / W=0.1$ for the heated vertical plate. The local heat-transfer-coefficients of the horizontal plate were also measured. The results show that the vertical adiabatic plate depresses the heat transfer while that the heated vertical plate enhances the heat transfer from the horizontal plates.
\end{abstract}

Key Words : Natural Convection, Heat Transfer, Visualization, Horizontal Plate, L-shaped Corner, Interaction

\section{1.}

加熱された水平面の端部に垂直壁が設圆された場合， あるいは加熱された垂直面の端部に水平面が設圈され た場合, 水平面や垂直面まわりに発生する自然対流の

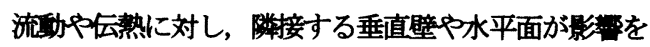
及ぼすことが知られている. このような体系は, 例え ぼ日射て暖められた地表と建物, 床暖房された室内と 壁, 熱交換器や工業炉などのコーナ部など様々な場面 で見られる体系であり，また，工学的には自然対流の 干渉が最も典型的に現れる体系であることから, 研究 者の興味を引き, 数多くの研究が行われている.

例えば, Rodighiero \& daSocio(1) は等温加熱された垂 直面の下端部に十分広い水平断熱面が接続された，い わゆる L 字型コーナまわりの自然対流について, 垂 直加熱面の局所熱伝達率を干涉計により測定している. その結果, 水平断熱面の存在により垂直加熱面の熱伝 達率が単独垂直平板のそれより $25 \%$ 程度低下するこ とを報告している. また Ruiz \& Sparrow》は，長さが 等しい水平および垂直面からなる等温加熱 L 字型コ

* 原稿受付 2003 年 2 月 14 日.

*1 正員, 姫路工業大学大学院工学研究科(E671-2201 姫路市 書写 2167).

*2 姫路工業大学大学院.

*3 正員, 豊橋技術科学大学機械システム工学系(①u 441-8580 豊橋市天伯町雲雀ヶ丘 1-1)。

E-mail : kimura@mech.eng.himeji-tech.ac.jp
一ナまわりの自然対流について，常温の水を対象に垂 直面および水平面の平均熱伝達率の測定と流れの可視 化を試みている. その結果, 垂直面の平均热伀達率は 単独垂直平板のそれに比べて低下すること, 逆に水平 面の平均热伀達率は単独水平平板のそれよりも高くな ることを報告している. 一方, Angirasa \& Mahajan(") は等温加熱された垂直伝熱面と，断熟あるいは周囲流 体温度に等温冷却された水平面からなる L 字型コー ナまわりの空気の自然対流について, 2 次元数值解析 を試み，垂直伝熱面まわりの局所およひ平均熱伝達率 の整理式を提案している.さらに，Balgï \& Venkateshan(\$，および Rao らめは，等温加熱された 水平伝熱面に垂直なアルミ製フィンを接絸した堭合に つい, 2 次元数値解析およひ涉計を用いた伝熱実 䀫を行い，垂直フィンまわりの伝熱特性に及ほす対流 およひ放射伝熱の影㛭を論じている.

これらの研究内容を詳しくみると, 従来の研究では, 垂直加熱面まわりの伝热特性に対して，加熱・冷却あ るいは断熱された水平面が如何なる影签を及ぼすかが 主たる関心事であることが分かる. 一方これとは逆, すなわち加熱水平面まわりの自然対流に対して, 垂直 面がどのような影督を及ぼすがついては，ほとんど 検討が行われていないことに気付く.これは一つには, 水平伝熱面まわりの自然対流が垂直伀熱面まわりのそ れに比べて熱的に不安定であり，容易に複雑か 3 次 
元的な流れとなるため，実験および解析的な取り扱い が困難であることが理由として挙げられる.

ところで，著者らはこのような水平伝熱面まわりの 自然対流の流動と伝熱について一連の検討を行ってい る(1) (10.，その結果によれば，水平伝熱面が単独で存在 する場合，伝熱面上には図 1 (a) に示寸ように，低温 の周囲流体が両端部から流入し, 伝熱面に沿って流れ, 伝熱面中央部で他端から来た流れと衝突，合流し，プ ルームとなって離脱・上昇する一連の流れが発生する ことを明らかにしている. そこで,つぎにこの水平伝 熱面の片側端部に垂直伝熱面が設置された場合を想定 してみる. 例えば水平伝熱面の大きさに比べて十分背

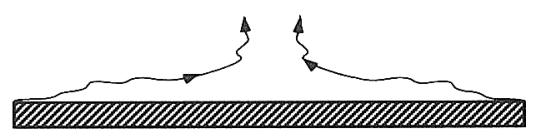

(a) without vertical plate

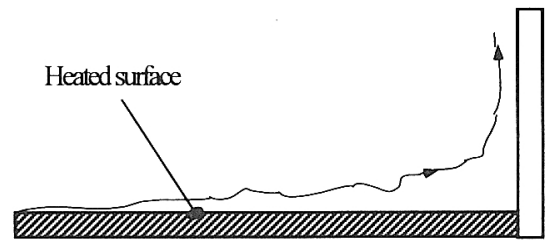

(b) with high vertical plate

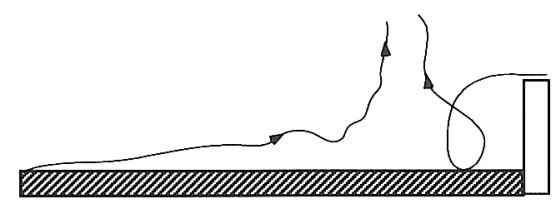

(c) with low vertical plate

Fig.1 Flow Fields over horizontal plate

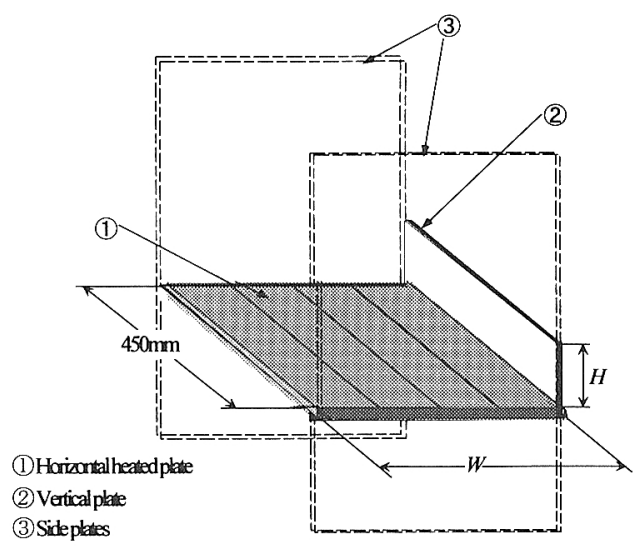

Fig.2 Experimental apparatus
の高い垂直壁が設置された場合には，図 1(b) に示す ように，水平伝熱面の開放端側から流入した流孔は垂 直壁に向かって流れ，そのまま垂直壁に沿って流出す ることが予想される. 一方，垂值壁の高さが低い場合 には, 図1(c)に示すように, 垂直壁側からも周囲流体 が流入して, 水平伝熱面まわりの流れは, 垂直壁を設 置しない場合とも, 背の高い垂直壁の場合とも異なる ことが予想される. また，この周囲流体の流孔込みに 対しては垂直壁の熱的条件が影響するであるう.しか し，このような水平伝熱面ま扣りの流れの変化がどの ような条件で生じるか，また，この流れの変化により 水平伝熱面からの伝熱がどのような影響を受けるかと いった問題については, 今まで系統的な研究が全く行 われておらず不明のままである.

このことから本研究では, 有限の大きさの水平上向 き伝熱面の片側端部に垂直壁が設置された場合を対象 に，水平伝熱面まわりの流動・伝熱に及ぼす垂直壁の 影響について実験的に検討することにした. 実験は, 水平伝熱面の大きさを 3 種類変化させ, 垂直壁につい ては断熱および等熱流束力熱した 2 通りの場合を取り 扱うことにした，そして，垂直壁を順次高くしていっ た場合について，まず水平伝熱面上の流動状況を染料 による流れの可視化により把握することにした。 い で，水平加熱平板の表面温度分布を感温液晶により可 視化し，伝熱面上の流動と局所伝熱特性との関連を探 った.さらに，水平加熱平板の局所熱伝達率を定量的 に測定し，水平伝熱面の局所伝熱特性に及ぼす垂直壁 の影響について論じることにした. 本研究の成果は垂 直加熱面まわりの伝熱特性に関する従来の研究成果と 共に, L 字型コーナ部まわりの伝熱・流動の全体像を 理解する上で役立つであるう。

\section{2. 实験䢂置および測定}

本研究で用いた実験装置の概略を図 2 に示寸、試験 流体には常温の水を用いた. 水平加熱平板は, 厚さ $15 \mathrm{~mm}$ のアクリル板に厚さ30pm のステンレス簿ヒー タを貼り付け，交流を通電することにより等熱流束条 件で加熱した. 垂直壁は, 厚さ $1 \mathrm{~mm}$ の塩化ビニル板 の片側表面にステンレス箔ヒータを，また裹面に厚さ $5 \mathrm{~mm}$ の硬質ウレタンフォーム断熱材を貼り付けた構 造となっている. 垂直壁を加熱する際には箔ヒー夕に 通電し，水平加熱平板と同一の表面熱流束となるよう にした．水平加熱平板の板幅 $W$ は $W=100,200$ お よび $350 \mathrm{~mm} の 3$ 種類，垂直壁の高さ $H$ は, $H=5,10$, $20,30,50,100$ および $150 \mathrm{~mm}$ の 7 種類変化させた. な 
お，水平平板および垂直壁の奥行きは，いずれも 450mm である. 伝熱面側方からの流体の流入を防止 するために，伝熱面の両側面に側板を取り付けた。こ れらの装置全体を $1 \mathrm{~m} \times 1 \mathrm{~m} \times 1 \mathrm{~m}$ の水槽底面中央部に 設置した. 水平加熱平板の局所表面温度 $T_{w_{X}}$ を測定す るために，水平加熱平板奥行き方向中心線上の䈃ヒー 夕裏面に線径 $100 \mu \mathrm{m} の \mathrm{~K}$ 型熱電対を所定の間隔でス ポット溶接した. 周囲流体温度 $T_{\infty}$ は, 水平加熱平板 と同一水平面上で，板端から $50 \mathrm{~mm}$ 離れた位置に熱 電対を設置し，測定した，実験に先立ち，水平平板裹 面および垂直壁裹面へ熱伝導により漏洩する熱量を見 積もったところ, 最大でもヒータ発熱量の $4 \%$ 以下で あった. そこで, 伝熱面表面熱流束 $q_{w}$ はヒー夕董面 への漏洩熱量を無視し，ヒータ発熱量を伝熱面表面積 で除すことにより算出した。

なお，これらの装置で実現可能な水平加熱平板の板 幅基淮の修正レイリ一数 $R a^{*}{ }_{W}\left(=g \beta q_{w} W^{4 /} \lambda \alpha \nu\right)$ は $2 \times 10^{9 \sim 2} 2 \times 10$ 22であった.

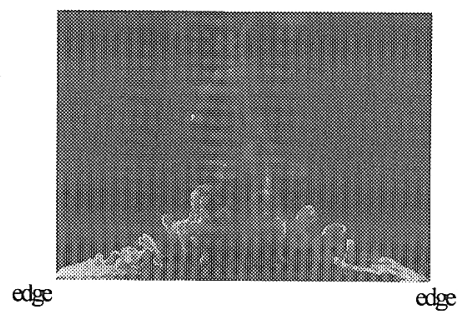

Fig.3 Visualized flow fields of horizontal plate

\section{3. 実験結果および考察}

\section{1 水平加熱平板まわりの流れの可視化}

まず，水平加熱平板の端部に垂直壁を設置しない場 合について，水平伝熱面まわりの流動を，染料を用い た流れの可視化により調べてみた．その結果の代表例

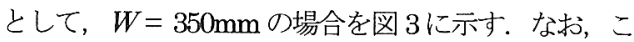
の図 3 は水平加熱平板の両端部にスリットを設置し, そこから色の異なる染料を膜状に流出させたときの流 動状況を，側方から写真撮影したものである。

図から明らかなように，平板端部から流出した染料 は，平板表面に沿ってわずかな距離流れた後，平板か らはく離する.このはく離した染料は，乱れながらも なお平板上を流孔て平板中央部に到達し，他端からの 流れと衝突・合流した後，プルームとなって鉛直上方 へ流れ去っていく、このうち平板端部付近で染料がは く離するのは，乱流遷移に先立って流れ方向に軸を持 つ縦渦が形成されることによるものであるの，なお， これと同様な流れは $W=100$ および $200 \mathrm{~mm}$ の伝熱面 においても観察された.

つぎに断熱垂直壁を水平加熱平板の片側端部に設置 した場合について，水平加熱平板上の流孔を可視化し てみた．その代表例として，板幅 $W=350 \mathrm{~mm}$ の水平 加熱平板の右側端部に, 高さ $H=10,30,50 \mathrm{~mm}$ の垂直 壁を設置した場合の結果を図 4 に示寸．水平平板の左 側端部（垂直壁非設置側）と垂直壁上端にスリットを 設置し，染料を流出させた。まず，垂直壁高さ $H=$

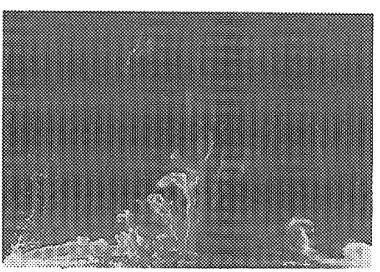

(a) $H=10 \mathrm{~mm}$

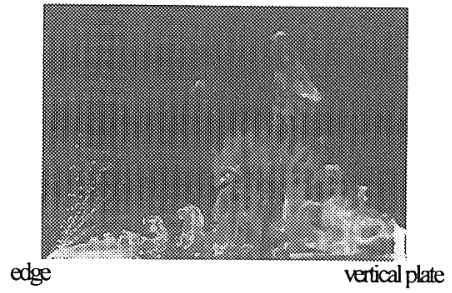

(b) $H=30 \mathrm{~mm}$

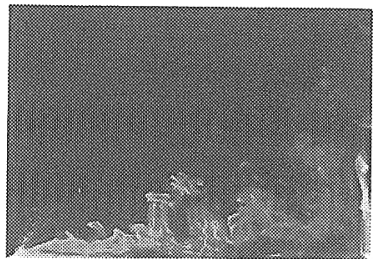

(c) $H=50 \mathrm{~mm}$

Fig.4 Visualized flow fields of horizontal plate with adiabatic vertical plate

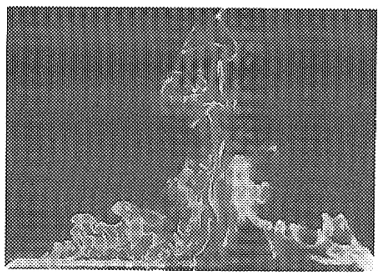

(a) $H=10 \mathrm{~mm}$

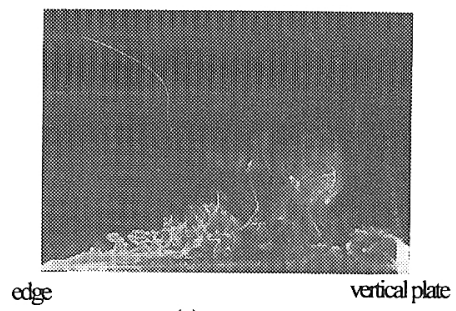

(b) $H=20 \mathrm{~mm}$

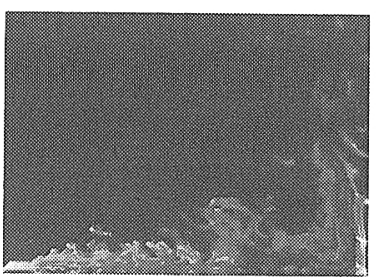

(c) $H=30 \mathrm{~mm}$

Fig.5 Visualized flow fields of horizontal plate with heated vertical plate 
$10 \mathrm{~mm}$ の場合であるが，図 4(a) から分かるように， 垂直䐴側から流出した染料は，垂直壁背後で不規則な 循襄渦を形成しながら水平平板上一流入し，他端から の流れと街突・合流してプルームとなって上方へ流れ 去っていく. また, その衙突・合流位膡は垂直壁が高 くなるに従って次第に垂直壁側へ移動していき，図 4(c) の $H=50 \mathrm{~mm}$ では，垂直䐴非設置側からの流れが そのまま垂直壁まで到達し, 垂直壁に沿って上方へ流 れ去る様子が読み取れる.

一方, 垂直壁を加熱した場合の代表的な可視化結果 として $W=350 \mathrm{~mm}, H=10,20,30 \mathrm{~mm}$ の場合を図 5 に 示す. 断熱壁の図 4(9) と同様, 垂直䐴高さ $H=10 \mathrm{~mm}$ の場合, 図 5(a)に示すように垂直壁側からの流れは 垂直壁の背後で不規則な循塁渦を形成しながら水平平 板上一流入し, 他端から来た流れと衙突・合流して上 方へ流れ去っていく.これに対して垂直壁高さ $H=$ $30 \mathrm{~mm}$ 以上になると, 垂直壁非設固側からの流れは そのまま垂直壁まで到達し，垂直壁に沿って上方へ流 れ去ることがわかる.

これらの結果から，とくに垂直碒の高さが低い場合 には, 垂直壁が加熱, 断熱を問わず, 垂直壁側から水 平平板に向かう流体の流れ込みが発生し，この流九込 みによって水平平板上の流れが大きな影䇾を受ける事 実が注目される.

\section{2 塔 - 合絃位}

以上の可視化によって, 垂直飳が低い場合, 水平加 熱平板上には垂直壁非設圈側からの流れと, 垂直壁側 からの流れの 2 つが存在することが分かった. これら 2 つの流れは, 水平平板上のある地点で衙突・合流し， 上方へ流れ去っていく.そこで本研究では，つぎにこ の衙突・合流位固が水平伝熱面の大きさ $W$, 伝熱面 熱流束 $q_{\text {m }}$ あるいは垂直壁の高さ $H$ によってどのよ うに変化するか流れの可視化結果を基に調べてみた. その結果を，垂直壁を断熱およひ加熱した場合につい て，図6およひ図 7にそれぞれ示す。これらの図の繸 軸には垂直壁非設置側から衙突・合流位置までの距離 $x_{c o l}$ を水平平板の板幅 $W$ て無次元化した值 $\left(x_{c o l} / W\right)$

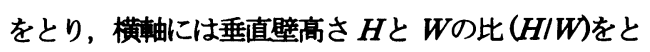
って表している. なお, 可視化䂓察の結果によれば, 街突・合流位膡は時間の経過に伴ってゆっくりと左右 に摇動することを確認している.そこで本実硂では， 可視化画像をビデオに一旦収録し，一定時間ごとに再 生した画像から衙突・合流位圈を求め, それらの平均 で衙突・合流位置を定義することにした。

まず，垂直壁を断熱した場合であるが，図6より， 無次元の街突・合流位置 $x_{c o l} / W$ は, データに若干の

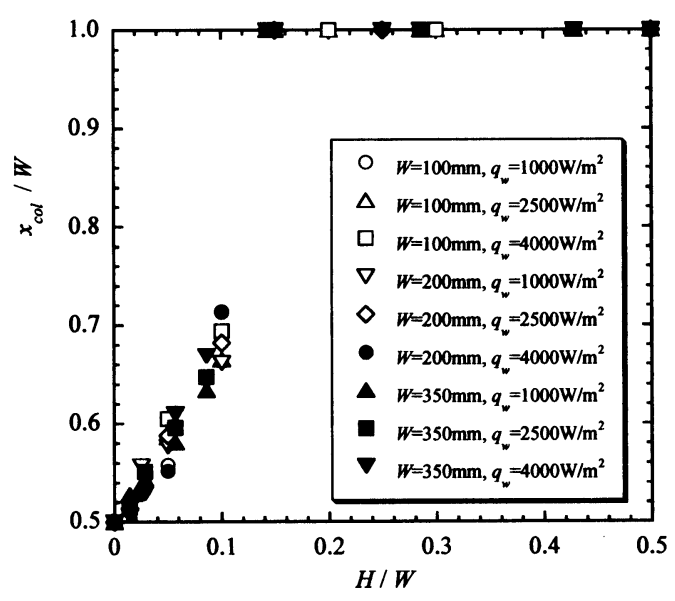

Fig.6 Location of collision point for adiabatic vertical plate

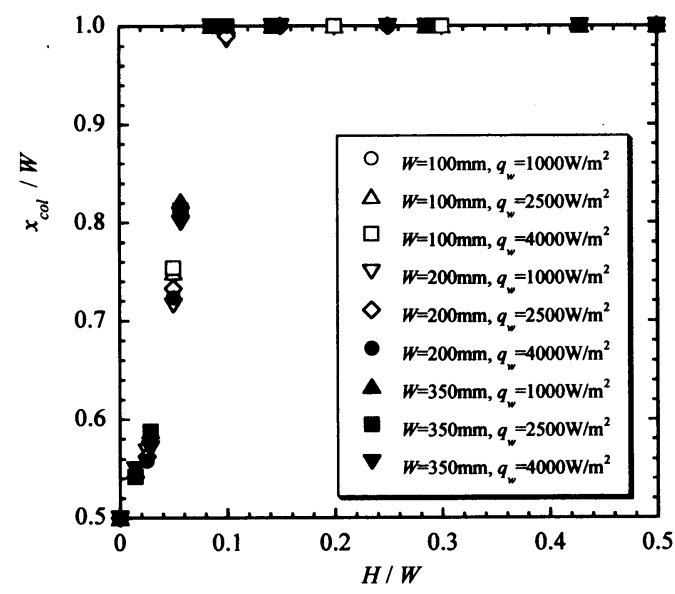

Fig.7 Location of collision point for heated vertical plate

ばらつきが見られるものの，本実験艒囲内においては 熱流束や水平平板の大きさに明確な依存性が見られず,

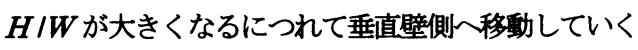
ことが分かる. そして, H/Wがおよそ 0.14 になると, 垂直壁側からの流九込みが無くなり，開放端則からの 流れが直接垂直壁まで到達することが分かる.

一方, 垂直壁が加熱された場合であるが，図７から，

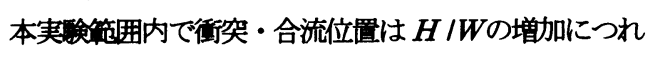
て急速に垂直壁側一移動していき, 伝熱面熱流束 $q_{w}$

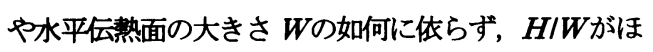
ほ 0.1 程度になると開放端側から流入した流れが直接 垂直䇒まで到達することが明らかである. また，この $H / W=0.10$ は断熱垂直壁に対する值 $H / W=0.14$ に比 べて小さく, 垂直壁が加熱された方が断熱された場合 よりも垂直壁側からの流れ込みが弱くなることが分か る. これは加熱垂直壁まわりに鉛直上向きの流れが発 
生し，この流れが垂直壁側からの周囲流体の流れ込み を阻止するためと考えられる。

\section{3 水平加熟平板表面温度分布の可視化}

以上の流九の可視化結果から, 水平伝熱面の端部に 垂直壁を設置することにより，水平伝熱面上の流れが 大きく変化することが分かった．そこで，これらの流 れの変化が水平伝熱面まわりの伝熱特性にどのような 影響を及ぼすか, つぎに伝熱面表面温度分布を感温液 晶シートによって可視化することにより調べてみた。

まず垂直壁を設置しない場合について，水平伝熱面 の温度分布を可視化した結果を図 8 に示寸。困 8 は $W=350 \mathrm{~mm}$ の水平加熱平板の温度分布を鉛直上方か ら写真撮影したものである。この写真の原図はカラー であり，モノクロの本図では色の識別が困難である. そこで, 可視化写真の見方について説明しておく. 本 春験で使用した感温液晶は, 温度の高いとき青色（白 黒写真ではグレーに見える）に，温度が低くなるにつ れて, 順次, 緑, 黄 (白黒写真では白く見える), 暗 赤色（白黒写真では黒く見える）八と色が変化する.

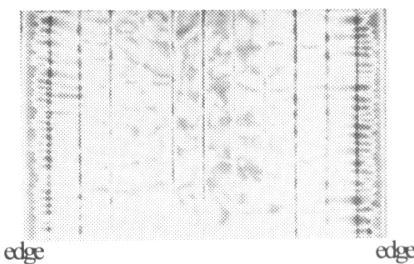

Fig.8Visualized surface temperatures of horizontal plate without vertical plate $(W=350 \mathrm{~mm})$
本実験では水平平板を等熱流束条件で加熱しているの で，図中温度の高い領域（グレーに見える）は熱伝達 率の低い領域を，温度の低い部分（黒く見える）は熱 伝達率の高い部分を表している。 なお，図 8 の縦方向 に一定間隔で低温線が見られるが，これは液晶シート の裏面にある箔ヒータの分割線であることを断ってお $<$.

さて, 水平加熱平板単独の場合, 図 8 から分かるよ うに，平板の温度分布は平板中心線に対して左右対称 となる，その温度変化であるが，まず平板左右端部付 近で温度は平板の奥行き（スパン）方向に一様となり， この領域での温度は端部から平板中央に向かって急激 に高くなる。乙して，板端から少し離れた地点から筋 状の低温模様が発生していることが分かる。この低温 筋状模様は，流れ方向に軸を持つ縦渦の発生に伴って 生じるものであるす，また，この筋状模様は板中央に 向からて伸び，次第に不規則な低温模様一と変化して いく様子が読み取れる。ささらに板中央部付近では，細 かで不規則な低温模様が発生している。この細かな低 温模様は伝熱面両端から来た流れが衝突・合流する際 に生じるもので，本図のような静止写真上では不明瞭 であるが，ビデオ動画像上では比較的明瞭に識別でき る. なお，これら一連の温度模様の成因等については 著者らの先の報告(に詳しく述べているので，本報で は説明を省略する.

さて，つぎに水平加熱平板の端部に断熱垂直壁を設 置した場合について，水平伝熱面の表面温度分布を可 視化してみた。 その代表例として，W=350 $\mathrm{mm}$ の水

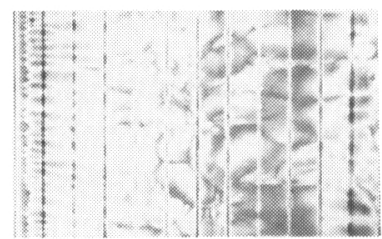

(a) $H=10 \mathrm{~mm}$

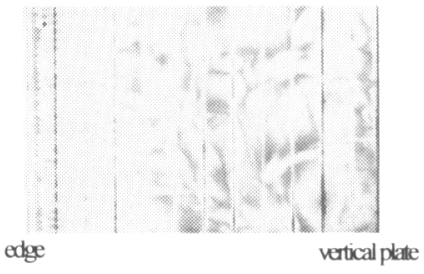

(b) $H=30 \mathrm{~mm}$

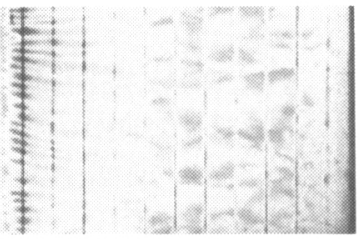

(c) $H=50 \mathrm{~mm}$

Fig.9 Visualized surface temperatures of horizontal plate with adiabatic vertical plate ( $W=350 \mathrm{~mm})$

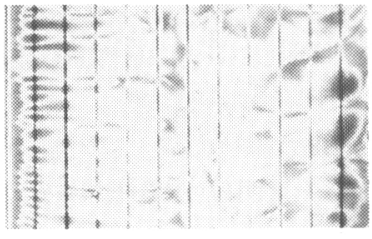

(a) $H=10 \mathrm{~mm}$

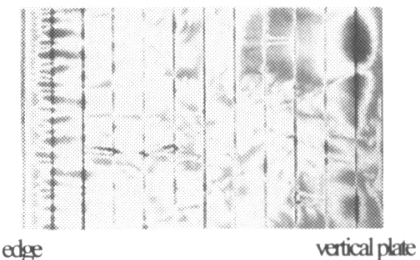

(b) $H=20 \mathrm{~mm}$

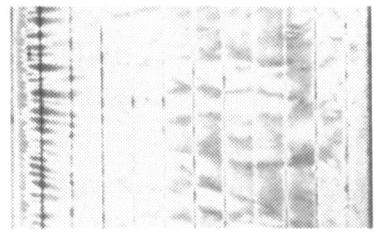

(c) $H=30 \mathrm{~mm}$

Fig.10 Visualized surface temperatures of horizontal plate with heated vertical plate $(W=350 \mathrm{~mm})$ 
平平板の右側に高さ $H=10,30,50 \mathrm{~mm}$ の非加熱垂直壁 を取り付けた場合の可視化結果を図 9 に示す。この図 9 のうち, まず開放端則の温度模様であるが，図 8 に 示した単独水平加熱平板と同様な温度模様が出現して いることが分かる. そして，垂直壁が高くなるに従つ て, とくに低温筋状模様の領域が垂直䐴側一伸びてい く結果が注目される. 一方, 垂直壁側の温度模様であ るが，垂直䐴が低い $H=10 \mathrm{~mm}$ の場合，図9(a)に示寸 ように垂直壁側に不規則でかなり大きなスケールの低 温模様が出現している. この低温模様の領域は, 前節 の流れの可視化結果によると, 垂直壁側から低温流体 が侵入し，垂直塈背後で不規則な循環渦を形成しなが ら流れる領域に対応しており,このような渦運動に伴 って低温模梯が生じたものと考えられる. なお,この 大きなスケールの低温模様は, 図 9(b) に示すように, 垂直壁が高くなるに従って次第に不明膫となり，垂直 壁側からの流れ込みが無くなる $H=50 \mathrm{~mm}$ では観察さ れなくなった. なお，図 9(c)では垂直暨近傍に細かな 模様が出現しているが，これは開放端則から流入した 流れが垂直壁に衙突する際に生じることを確認してい る.

つぎ，垂直壁を加熱した場合について水平伝熱面 の表面温度分布を可視化してみた. その代表例として, $W=350 \mathrm{~mm}$ の水平伝熱面について, 加熱垂直壁高さ を $H=10,20,30 \mathrm{~mm}$ としたときの結果を図 10 に示す. この図 10 と, 図 9 の断热垂直壁の可視化結果を詳し く比較してみると, 例えば $H=30 \mathrm{~mm}$ の断熱垂直壁で は，図 9(b) に示すように垂直壁近傍に垂直壁側から の流体の侵入に伴う大きなスケールの低温模様が発生 しているのに対して，同じ高さの加熱垂直壁では，図 $10(c)$ に示すように大きなスケールの温度模様が稓察

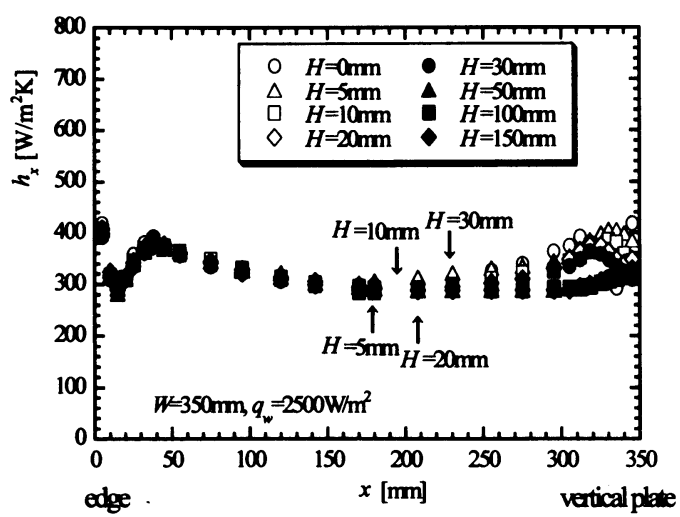

(a) with adiabatic vertical plate
されないなどの差異がみられる.これは垂直壁側から の流体の流入が垂直面の加熱条件によって変化するた めである. しかし, これらの点を除けば, 水平伝熱面 の温度模様の変化は, 加熱垂直壁と断熱垂直壁の場合 とで基本的に変わらないことが分かる.

\section{4 水平加的平板の伝西特性}

以上の可視化結果を参考にして, つぎに熱電対を用 いて水平加熱平板の局所熱伝達率を定量的に測定して みた. この水平加熱平板の局所熱伝達率 $h_{x}$ であるが, 次式により求めた。

$$
h_{x}=q_{w} /\left(T_{w_{x}}-T_{\infty}\right)
$$

ここで， $q_{w}$ は伝熱面表面熱流束， $T_{w_{x}}$ は水平加熱 平板の局所表面温度, $T_{\infty}$ は周囲流体温度である. 図 8～10 の伝熱面表面温度分布に示したように，開放端 側のとくに低温笳状模様が発生する領域では，局所熱 伝達率が平板のスパン方向に大きく変化する. そこで 本研究では，局所熱伝達率をスパン方向に平均した值 で定義することにした. その具体的な測定力法につい ては，前報は訳詳しく記しているので省略する.

さて, その代表的な例として, 水平伝熱面の幅 $W=$ $350 \mathrm{~mm}$, 熱流束 $q_{w}=2500 \mathrm{~W} / \mathrm{m}^{2}$ の結果を, 図 11(a) お よひ図 11(b)に示す. 図 11(a) は断熱垂直壁を, また 図 11(b) は加熱垂直壁をそれぞれ設置した場合の結果 を示したもので，両図とも，横軸には開放端から垂直 壁設置側に向かう流九方向の距離 $\boldsymbol{x}$ を，縦軸には局所 熱伝達率 $h_{x}$ をとっている. なお可視化により求めた 衝突・合流位置を参考までに, 図 11 中によ印で示し た.

まず，垂直平板を設置しない $H=0 \mathrm{~mm}$ の結果であ るが，図 11(a) に示すように，局所熱伝達率は水平加 熱平板の中心線に対して左右対称な分布となり，その

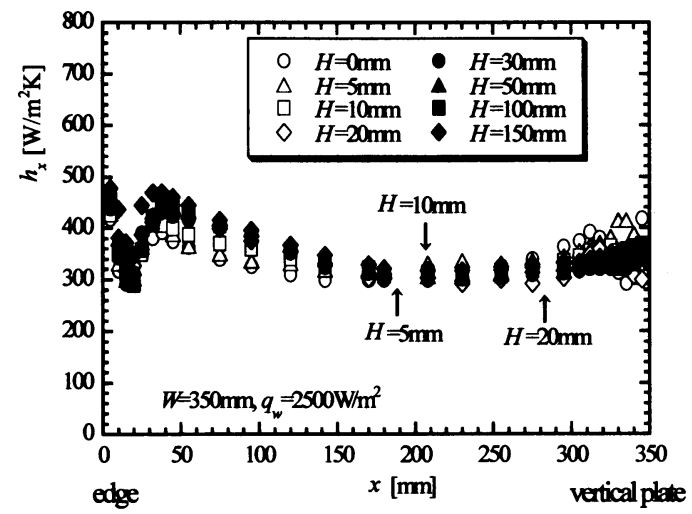

(b) with heated vertical plate

Fig.11 Local heat transfer coefficients of the horizontal plate $\left(W=350 \mathrm{~mm}, q_{w}=2500 \mathrm{~W} / \mathrm{m}^{2}\right)$ 
值は伝熱面両端部で最も高く，伝熱面端部から少し離 れた位置で極小值を示した後, 今度は增加に転じ, 極 大値を示した後, 平板中央に向かって緩やかに低下し ていくことが分かる. このうち熱伝達率の極小值は, 伝熱面端部から流入した低温周囲流体が伝熱面表面に 沿って流れ，伝熱面からはく離し始める直前の位謴に 対応しており，層流境界層流域の終端に，また局所熱 伝達率の極大值は，図 8 の温度分布の可視化で低温筋 状模様が最も抗大した位置に対応していることを確認 しているき.

これに対して，伝熱面右側端部に垂直断熱壁を設置 すると, 図 11(a) 中】印で示した衝突・合流地点から 垂直壁までの領域で, 全般的に局所熱伝達率が大きく 低下する結果が注目される. この領域の局所熱伝達率 を詳しく見てみると，垂直壁が $H=5,10,20 \mathrm{~mm}$ と高 くなるにつれて, 単独水平平板で見られた極小・極大 值が次第に不明瞭となり， $H=50 \mathrm{~mm}$ 以上になると熱 伝達率分布に極小・極大值が現われなくなることが分 かる. これは垂直壁が高くなるにつれて，垂直壁側か らの周囲流体の流れ込みが弱まるためで, 図 9 に示し た温度分布の可視化結果とも符合する.

一方, 水平平板の開放端から衝突・合流位置までの 局所熱伝達率であるが, 垂直壁高さ $H$ の如何に依ら ず，その分布は垂直壁の無い場合のそれに一致するこ とが分かる.この結果は, 開放端側の伝熱特性に対し て，断熱垂直壁が実質的に影響を及ぼさないことを示 しており興味ある結果といえる. そこで，この開放端 から図中】印で示した衝突・合流域までの局所熱伝達 率 $h_{x}$ について, 開放端からの距離 $\boldsymbol{x}$ を代表長さとす る局所ヌッセルト数 $N u_{x}\left(=h_{x} \cdot x / \lambda\right)$ を算出し, 同じ く $\boldsymbol{x}$ を代表長さにとった局所修正レイリー数 $R_{a x}{ }^{*}(=$ $\left.g \beta q_{w} X^{4 /} \lambda \alpha \nu\right)$ を用いてプロットし直してみた. その結果を図 12 に示す. 著者ら 78 は先に, 本実験よ りも更に板幅の大きな単独水平加熱平板について局所 ヌッセルト数の測定を行い，その結果を基に実験整理 式を提案している. その結果を図 12 中に害線で示し た.この図 12 から明らかなように, 開放端から衝 突・合流地点までの局所ヌッセルト数は, 単独水平平 板のそれと良好に一致している. また垂直壁高さ $H$ $=50 \mathrm{~mm}$ 以上の本実験值については, 開放端から垂直 壁に至る全てのデータを図に記したが，その結果は従 来の単独水平平板の整理式に良好に一致している. こ のことから断熱垂直壁が十分高い場合には, 開放端か ら垂直壁までの伝熱特性は，開放端から垂直壁までの 距離を半幅とする単独水平加熱平板の局所ヌッセルト 数にほぼ一致することが分かる.

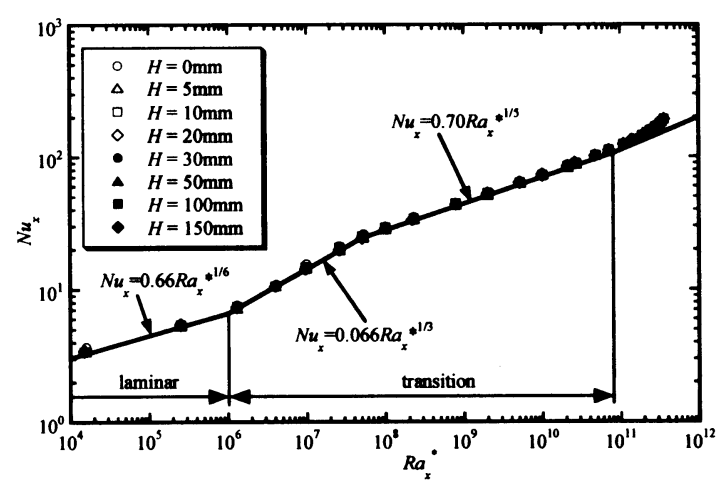

Fig.12 Local Nussett numbers of horizontal plate (framopen edgetocollision points)

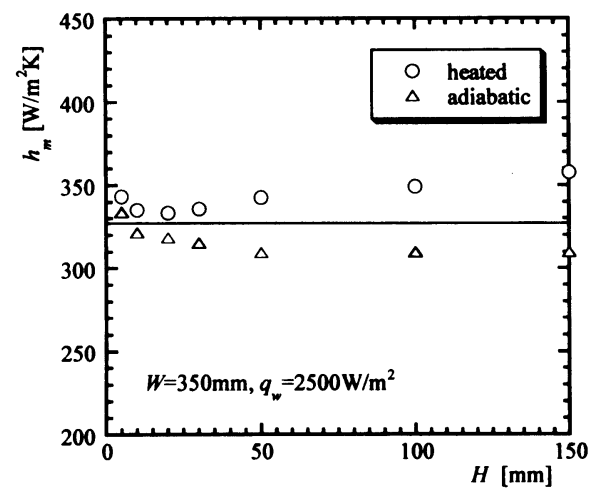

Fig.13 Comparison of overall heat transfer coefficients

つぎに垂直壁を加熱した場合の局所伝熱特性につい て述べる. 図 11(b) から，加熱垂直壁を $H=5,10,20$ $\mathbf{m m}$ と次第に高くしていくと, 開放端側の局所熱云達 率は全般的に高くなり，逆に垂直碒側の局所熱伝達率 は低下していく様子が読み取れる.このうち垂直壁側 の熱伝達率が低下するのは，垂直壁側からの周囲流体 の流入が弱まるためであり，前述した断热垂直壁の場 合と同椂な理由による. 一方, 開放端側の熱伝達率が 増加するのは，加熱垂直暨によって高温流体の排出が 促隹され，この流れを補うように水平伝熱面の開放端 側からより多くの低温流体が流れ込むためと考えられ る. このような加熱垂直暨による流れの誘引効果が, 本実験で用いたような $W=350 \mathrm{~mm}$ という大きな水平 伝熱面まわりの伝熱に対して無視し得ない影烈を及ぼ すという事実は，垂直伝熱面の影勡がかなり上流側に まで及ぶことを示唆しており, 注目すべき結果である といえる.

最後に以上の局所熱伝達率の測定結果から，参考 までに水平加熱平板全体の平均熱伝達率 $h_{m}$ を求めて 
みた. その代表例として, 幅 $W=350 \mathrm{~mm}$ の水平伝熱 面の平均熱伝達率を断熱およひ加熱垂直壁の場合につ いて比較した結果を図 13 に示す. なお, 図中の実線 は垂直壁の無い単独水平加熱平板の平均熱伝達率を示 している.この図 13 より, 断熱垂直壁を設置した場 合, 水平伝熱面の平均熱伝達率は垂直壁が高くなるに つれて緩やかに低下していき, 垂直壁側からの流れ込 みが無くなる $H=50 \mathrm{~mm}$ 以上では, 一定の值を示すこ とが分かる. 一方, 加熱垂直壁を設置した場合の平均 熱层達率は， $H$ が大きくなるにつれて緩やかに増加 していくことが分かる. これは前述した垂直加熱壁に よる誘引効果によって伝熱が促進されるためである. このように，垂直壁を断熱した場合と加熱した場合と て水平伝熱面まわりの伝熱特性が大きく異なる結果は 今まで全く報告されておらず興味深い結果といえる.

\section{4. 鼓}

本研究は，等熱流束条件で加熟された水平上向き加 熱平板の片側端部に垂直壁を設直した，いわゆる $\mathrm{L}$ 字型コーナまわりの自然対流の流動と伝熱について実 験的に検討したものである. 試験流体に常温の水を用 い, 垂直壁が断熱された場合, および水平加熱平板と 同一の熱流束で加熱された場合のそれぞれについて, とくに水平加熱平板まわりの伝熱・流動を中心に，流 れと表面温度分布の可視化実験および伝熱実験により 探った. 実験は水平加熱平板の板幅 $W$ を 100,200 お よび $350 \mathrm{~mm}$ の 3 種類変化させ, 垂直壁の高さを 5 150mm まで順次系統的に変化させていった場合に ついて行った. これらの実験により，以下のような結 果が得られた.

(1)垂直壁が低い場合, 垂直壁設固側から周囲流体が 流れ込み，垂直壁背後で不規則な渦を形成して水平加 熱平板上一進入し, 垂直壁非設圈側からの流れと衔 突・合流し，プルーム状となって上方へ流れ去る一連 の流れが生じることを確認した. また, 水平伝熱面上 の衙突・合流位固は，垂直壁が高くなるにつれて次第 に垂直壁側一移動することが分かった.

(2)垂直壁がある程度以上高くなると，水平伝熱面の 開放端側から流入した流れは，そのまま垂直壁まで到 達し, 垂直壁に沿って上方へ流れ去ることを確認した. また, この流れが実現される条件は, 垂直壁高さ $H$ と水平伝熱面の大きさ $W$ との比 $H W$ によって与えら
れ，断熱垂直壁の場合， $H W=0.14 ，$ 加熱垂直壁の場 合 $H W=0.1$ 程度の值となる.

（3）断熱垂直壁を設置した場合について，水平加熱平 板の流れ方向局所熱伝達率を測定したところ, 垂直壁 近傍の熱伝達率は垂直壁が高くなるにつれて次第に低 下する結果が得られた. また，この熱伝達率の低下は 垂直壁によって水平伝熱面に向から低温流体の流九込 みが抑制されるために生じることを確認した. 一方, 水平伝熱面の開放端から衝突・合流位置までの局所熱 伝達率は, 単独水平平板の局所熱伝達率に一致し, 垂 直壁の影響を受けないことが分かった.

(4)加热垂直壁を設置した場合について水平加熱平板 の局所熱伝達率を測定した. その結果, 垂直壁近傍の 熱伝達率は垂直壁が高くなるにつれて低下する一方, 開放端則の局所熱伝達率は単独水平平板のそれよりも 顕著に増加することを明らかにした. とくに後者の熱 伝達率の増加が, 加熱垂直壁による流れの誘引効果に よることを指摘した.

(5)上述した局所熱伝達率の変化により, 断熱垂直壁 を設置した場合の水平加熱平板まわりの平均熱伝達率 は, 単独水平平板の平均熱伝達率よりも低くなること, 逆に加熱垂直壁を設置した場合の平均熱伝達率は, 単 独水平平板のそれより高くなることが分かった.

\section{文献}

(1) Rodighiero, C. and deSocio, L M, Trans ASME, J. Heat Transf, 105(1983), 212-214.

(2) Ruiz, R. and Sparrow, E. M, Int. J. Heat Mass Transf, 30(1987), 25392548.

(3) Angirasa, D. and Mahajan, R. L , Trans ASME, J. Heat Transf, 115 (1993), 149157.

(4) Balaj,C. and Venkateshan, S. P., Trans ASME, J. Heat Transf, 118(1996), 222-225.

(5) Rao, VR., Balä̈, C. and Venkateshan, S.P., Int. J. Heat Mass Transf, 40(1997), 2941-2947.

(6) 北村·木村, 機論，58-556，B(1992)，3715-3722.

(7) 木村 · 北村, 機論, 60-570, B(1994), 566-573.

(8) Kitamura, K. and Kimura, F, Int. J. Heat Mass

Transf, 38-17,(1995) 3149-3159.

(9) 北村・ ほか2名, 機綸, 65640, B(1999), 40334040.

(10)木村 • ほか 2 名, 機綸, 68-669, B(2002), 15151522 